\title{
Glucocorticoids, the Hippocampus, and Behavioral Inhibition in the Preweanling Rat
}

\author{
Lorey K. Takahashi \\ Department of Psychiatry, University of Wisconsin Medical School, Madison, Wisconsin 53792-2475
}

Endogenous corticosteroids influence brain development and behavioral expression. In rat pups, a corticosteroiddependent developmental response is behavioral inhibition, which occurs in situations involving threat. Behavioral inhibition consists of freezing and a reduction in ongoing behavior. It is presently unknown which brain region(s) that bind corticosterone (CORT) is involved in the development of freezing. The hippocampus (HC), however, is the principal target site of CORT that regulates the postnatal development of HC dentate granule cells. Therefore, this study examined whether the $\mathrm{HC}$, and in particular, the dentate granule cells, plays a major role in the early appearance of behavioral inhibition.

On postnatal day 9, rat pups received bilateral $\mathrm{HC}$ electrolytic lesions, or bilateral $\mathrm{HC}$ infusions of colchicine, a neurotoxin selective for dentate granule cells, or bilateral $\mathrm{HC}$ infusions of kainic acid, a neurotoxin selective for pyramidal cells in the CA3 field. Control rats received sham operations. After the operations, all rats were adrenalectomized (ADX) and injected daily with $3.0 \mathrm{mg} / \mathrm{kg}$ CORT, except on the day of the behavioral test. On day 14, all pups were tested for behavioral inhibition, which consisted of removing the pup from the nest box and placing it in a temperature-controlled enclosure subdivided into two compartments by a wire-mesh partition. The pup was placed in one compartment and an unfamiliar anesthetized adult male rat was placed in the adjacent compartment. Results indicated that preweanling rats with electrolytic lesions ranging from the dorsal to the ventral $\mathrm{HC}$ exhibited significant deficits in freezing. Importantly, similar deficits in freezing were present in pups treated with colchicine but not KA. Hence, administration of exogenous CORT is not effective in facilitating the occurrence of freezing in preweanling pups lacking dentate granule cells. To determine whether the dorsal $\mathrm{HC}$ dentate gyrus is an essential target site of CORT in facilitating freezing, 9-d-old rats were implanted bilaterally with $\mathbf{3 0}$ gauge cannula filled with either CORT or cholesterol. After the operation, all rats were ADX and tested for behavioral inhibition on day 14. During testing, ADX pups with CORT-filled cannulae showed significantly higher levels of freezing than ADX control pups.

\footnotetext{
Feb. 27, 1995; revised Apr. 24, 1995; accepted Apr. 28, 1995.

This work was supported by NIMH Grant MH-43986 and by research funds provided by the Graduate School. The author thanks D. Hollander and $\mathrm{K}$. Bondy for technical assistance, and Dee Jones for secretarial assistance.

Correspondence should be addressed to Dr. Lorey K. Takahashi, Department of Psychiatry, University of Wisconsin Medical School, 600 Highland Avenue, Madison, W1 53792-2475.

Copyright (C) 1995 Society for Neuroscience $0270-6474 / 95 / 156023-12 \$ 05.00 / 0$
}

Taken together, results suggest that during the early postnatal period, the action of endogenous CORT in the HC influences the development of dentate granule cells that play an essential role in mediating the appearance of behavioral inhibition.

[Key words: adrenalectomy, behavioral inhibition, corticosterone, dentate gyrus, freezing, glucocorticoids, hippocampus, preweanling rat, ultrasonic vocalization]

Behavioral inhibition is an adaptive response exhibited by vertebrates when threatened (Palmer, 1909; Ratner, 1967; Schaller, 1972, Curio, 1976). It consists of immediate cessation of ongoing bchavior accompanicd by a prominent immobile posture or freezing response. Understanding the neurobiology of behavioral inhibition may offer critical insights into the pathophysiology of anxiety disorders (Gray 1982; Kagen et a1., 1988; Biederman et al., 1990). Therefore, identification and characterization of the neural systems mediating freezing are currently the focus of intense research (LeDoux, 1987; Blanchard and Blanchard, 1988; Davis, 1992).

This laboratory has adopted a developmental approach to the study of behavioral inhibition in an effort to obtain much-needed information on the basis underlying early individual differences in stress-induced responses. Preweanling rodents removed or isolated from the nest often emit ultrasonic vocalizations (Zippelius and Schleidt, 1956; Hart and King, 1966; Noirot 1966, 1968; De Ghett, 1974) that are capable of attracting the attention of the nursing dam (Allin and Banks, 1972; Noirot, 1972; Smotherman et al., 1974). In preweanling rats, this propensity to emit ultrasounds during social isolation, however, is reduced in the presence of an unfamiliar adult male rat (Takahashi, 1992a,b), a potentially infanticidal threat (Rosenberg et al., 1971; Takahashi and Lore, 1982). Concurrent with the reduction in ultrasound production is the display of freezing. This ability of rat pups to exhibit these reciprocal patterns of behavior appears near the end of the second postnatal week (Takahashi 1992a,b), which may reflect the emergence of recently matured physiological systems.

Although the neural system underlying the development of behavioral inhibition remains to be elucidated, it is especially notable that rats adrenalectomized (ADX) on postnatal day 10 exhibit pronounced deficits in behavioral inhibition when tested subsequently on day 14 (Takahashi and Rubin, 1993). This ADX-induced impairment in behavioral inhibition is reversed after administration of exogenous corticosterone (CORT), the major glucocorticoid of the rat, either systemically or directly into the brain (Takahashi and Rubin, 1993; Takahashi and Kim, 1994). Because glucocorticoids are implicated in brain development (Sze et al., 1976; Doupe and Patterson, 1982; Meyer, 
1985), it is possible that neural sites that bind endogenous CORT have a major involvement in the developmental expression of behavioral inhibition.

A likely neuroanatomical target of CORT whose development appears to coincide with the ability of rats to express behavioral inhibition is the hippocampus (HC). Anatomical studies indicate that the $\mathrm{HC}$, in particular, dentate granule cells, shows considerable postnatal development during the early preweaning period (Altman and Das, 1965; Schlessinger et al., 1975; Bayer 1980a,b; Cowan et al., 1980). Furthermore, prior to the end of the second postnatal week, adrenal steroids play a prominent role in regulating granule cell genesis and cell death (Gould et al., $1991 \mathrm{a}, \mathrm{b}$ ). The mechanism(s) by which adrenal steroids produce their effects on $\mathrm{HC}$ cells is not clear but may be via hormone receptor activation because of the high density of adrenal steroid receptors located in the HC (Stumpf, 1971; Gerlach and McEwen, 1972; Rosenfeld et al., 1988a,b, 1990; Sarrieau et al., 1988; Lawson et al., 1991; Van Eekelen et al., 1991). Finally, behavioral studies suggest that the $\mathrm{HC}$ is involved in controlling some forms of response suppression or inhibition (Douglas 1967; Altman et al., 1973; De Kloet et al., 1988). Taken together, data suggest that CORT-induced developmental changes occurring in the $\mathrm{HC}$ may have a critical role in facilitating the ontogeny of behavioral inhibition. Therefore, the purpose of this study was to provide the first step to address the fundamental question of whether or not the developing rat $\mathrm{HC}$ plays a major role in the appearance of behavioral inhibition.

Some of these results appeared in abstract form (Takahashi, 1994a).

\section{Materials and Methods}

Animals. Rat pups were offspring of Sprague-Dawley female rats (75$90 \mathrm{~d}$ old) derived from a stock obtained from Sasco, Madison, WI. Rats were maintained on a $12 \mathrm{hr} / 12 \mathrm{hr}$ light/dark cycle, with lights on at $0600 \mathrm{hr}$. After mating, female rats were housed singly in stainless steel hanging cages until day 20 of pregnancy when they were transferred to plastic breeding cages $(31 \times 22 \times 18 \mathrm{~cm})$ with wire-mesh tops. Each cage was provisioned with food, water, and a layer of wood shavings. Breeding cages were checked daily for the presence of pups (day of birth $=$ postnatal day 0 ). Litters were left undisturbed except for routine cage cleaning. Sexually experienced adult male Sprague-Dawley rats, housed in an adjacent room, were used as stimulus animals.

Electrolytic lesions. On postnatal day 9, two male pups were taken from each litter $(n=11)$ and assigned to either the lesion or the shamoperation group. Pups were anesthetized with methoxyflurane (PitmanMoore, Mundelein, IL) and placed in a stereotaxic apparatus adapted for neonatal rats (David Kopf Instruments, Tunjunga, CA). A stainless steel $0.2 \mathrm{~mm}$ diameter wire insulated with Epoxylite except for $0.5 \mathrm{~mm}$ at the tip was used for passing anodal current from a constant de source (Model DCLM5A, Grass Instrument Company, Quincy, MA). Lesions were made by passing $1.5 \mathrm{~mA}$ current for $15 \mathrm{sec}$ with the electrode positioned at three sites within each $\mathrm{HC}$. The following flat-skull coordinates were used: $\mathrm{A}-\mathrm{P}=-2.0 \mathrm{~mm}$ from bregma, $\mathrm{M}-\mathrm{L}= \pm 1.0 \mathrm{~mm}$, $\mathrm{D}-\mathrm{V}=-3.0 \mathrm{~mm}$ from the skull surface; $\mathrm{A}-\mathrm{P}=-3.8 \mathrm{~mm}$ from bregma, $\mathrm{M}-\mathrm{L}= \pm 3.5 \mathrm{~mm}, \mathrm{D}-\mathrm{V}=-3.4 \mathrm{~mm}$ and $-5.4 \mathrm{~mm}$ from the skull surface. Identical electrode placement procedures were used for shamoperated rats except no current was passed. After stereotaxic surgery, all pups were ADX and treated with CORT.

Two sham-operated controls died prior to testing and two HC-lesioned rats appeared sick and were not tested. Therefore, data were obtained from nine sham-operated (body weight $=25.8 \pm 0.9 \mathrm{gm}$ ) and nine IIC-lesioned $(23.9 \pm 0.3 \mathrm{gm})$ rat pups.

Destruction of hippocampal dentate granule cells. Two male pups were taken from each litter $(n=11)$ and prepared for stereotaxic surgery on day 9 . Colchicine infusions were made with a 28 gauge stainless steel cannula connected to a microliter syringe by polyethylene tubing. The microliter syringe was driven by an infusion pump. Colchicine (Sigma Chemical, St. Louis, MO) was dissolved in deionized water and $25 \mathrm{ng}$ was infused in a volume of $0.25 \mu \mathrm{l}$ over a $60 \mathrm{sec}$ period. The infusion cannula remained in place for an additional $90 \mathrm{sec}$. Control pups were infused with vehicle. Each $\mathrm{HC}$ was infused with vehicle or colchicine at two locations using the following flat-skull coordinates: A-P $=-2.0 \mathrm{~mm}$ from bregma, $\mathrm{M}-\mathrm{I},= \pm 1.0 \mathrm{~mm}, \mathrm{D}-\mathrm{V}=$ $-3.0 \mathrm{~mm}$ from the skull surface; A-P $=-3.8 \mathrm{~mm}$ from bregma, $\mathrm{M}-\mathrm{L}$ $= \pm 3.6, \mathrm{D}-\mathrm{V}=-4.4 \mathrm{~mm}$ from the skull surface. All rat pups were ADX and administered CORT after the opcration.

Two sham-operated controls and one colchicine-treated pup died prior to testing. Thus, histological and behavioral data were obtained from nine controls (body weight $=26.7 \pm 0.7 \mathrm{gm})$ and $10(25.9 \pm 0.2 \mathrm{gm})$ colchicine-treated rats.

Destruction of hippocampal CA3 cells. Two 9-d-old male pups were obtained from each litter $(n=9)$ and received either sham operations or infusions of KA in the HC. KA infusions were made with a 28 gauge stainless steel cannula. KA (Sigma Chemical, St. Louis, MO) was dissolved in sterile saline and $100 \mathrm{ng}$ was infused in a volume of $0.5 \mu \mathrm{l}$ over a $120 \mathrm{sec}$ period. The infusion cannula remained in place for an additional 90 sec. Control pups were infused with vehicle. Each HC was infused with vehicle or KA at two locations using the following flat-skull coordinates: $A-P=-2.0 \mathrm{~mm}$ from bregma, $\mathrm{M}-\mathrm{L}= \pm 2.0$ $\mathrm{mm}, \mathrm{D}-\mathrm{V}=-3.0 \mathrm{~mm}$ from the skull surface; $\mathrm{A}-\mathrm{P}=-3.8 \mathrm{~mm}$ from bregma, $M-L= \pm 3.6, D-V=-5.4 \mathrm{~mm}$ from the skull surface. After the operation, all pups were ADX and injected with exogenous CORT. In adult rats, systemic administration of KA elicits seizures (Cherubini et al., 1983; Albala et al., 1984; Ben-Ari et al., 1984; Tremblay et al., 1984; Sperber et al., 1991). Therefore, KA infused pups were observed periodically in the nest box during a $3 \mathrm{hr}$ postoperative recovery period. Behavior indicative of seizure activity was not observed.

One sham-operated pup died prior to day 14. Therefore, a total of eight control pups (body weight $=24.3 \pm 0.2 \mathrm{gm}$ ) and nine KA-treated rats $(24.0 \pm 24.0 \mathrm{gm})$ were tested.

Histological verification of lesions. Upon completion of behavioral testing, pups were overdosed with sodium pentobarbital and perfused intracardially with $0.9 \%$ saline followed by $10 \%$ formalin. Brains were removed and kept in $10 \%$ formalin followed by $20 \%$ sucrose-formalin for cryoprotection. Frozen sections were cut at $60 \mu \mathrm{m}$ and every third section was mounted throughout the extent of the lesion and stained with thionine. The magnitude and placement of lesions and cannulae were determined with the aid of a 10-d-old rat brain atlas (Sherwood and Timiras, 1970).

Implantation of CORT in the dorsal HC. Two 9-d-old male pups were obtained from each litter $(n=11)$ and assigned randomly to either cholesterol or CORT implantation groups. Implantation procedures consisted of bilateral placements of 30 gauge stainless steel cannula containing cholesterol or CORT (Sigma Chemical) in the dorsal HC. Cannulae were filled with molten cholesterol or CORT. After solidifying, the outer tip of the cannula was cleaned with ethanol to ensure that hormone was available only at the surface of the lumen. The following flat-skull coordinates were used: A-P $=-2.0 \mathrm{~mm}$ from bregma, M-L $= \pm 2.0 \mathrm{~mm}, \mathrm{D}-\mathrm{V}=-3.0 \mathrm{~mm}$ from the skull surface. After the operation, ADX procedures were conducted.

Prior to returning the ADX pup to the nest box on day 10 , an s.c. injection of $8 \mu \mathrm{g} / 100 \mathrm{~g}$ body weight of aldosterone (Sigma Chemical) was administered. A second aldosterone injection was administered on day 12. This dose of aldosterone facilitates survival in ADX pups and does not promote the development of hehavioral inhibition (Takahashi and Rubin, 1993; Takahashi, 1994c).

After testing, pups were prepared for perfusion and brain histology as described previously, with the exception that a blood sample was taken from the heart prior to perfusion with a syringe. Blood samples were placed in ice-chilled microcentrifuged tubes containing EDTA. Tubes were centrifuged in an Eppendorf microcentrifuge (Brinkman Instrument, Westbury, NY) for a duration of 3 min. Plasma was aliquoted and stored at $-70^{\circ} \mathrm{C}$ until the time of assay for CORT.

Cannulae were removed from the brain and the lumen examined using a microscope for the presence of hormone. Inspection of cannulae revealed that although hormone was recessed in the lumen, all cannulae contained hormone. Cannulae were then allowed to dry, weighed, refilled with CORT, and reweighed to determine the amount of CORT dissolved during the period of implantation.

Duplicate plasma samples were analyzed in one assay for CORT using a ${ }^{12.5}$ CORT kit (Diagnostic Products, Los Angeles, CA). The antiserum exhibits a cross-reactivity to 11-deoxycorticosterone of < $2.9 \%$. Cross-reactivity to other adrenal steroids was $<0.9 \%$ ). The de- 
tection limit of the assay was $1.5 \mathrm{ng} / \mathrm{ml}$. The intraassay coefficient of variation was $4.0 \%$.

One cholesterol-implanted pup died prior to day 14. In addition, two CORT-implanted pups had high plasma concentrations of CORT (mean $=49.5 \mathrm{ng} / \mathrm{ml}$ ) and were excluded from the data analysis. Plasma concentrations of CORT in the remaining CORT-implanted pups as well as $\Lambda D X$ pups implanted with cholesterol-filled cannulae were below the level of detection of the assay. Therefore, behavioral analyses were performed on data obtained from 10 cholesterol- (body weight $=24.9$ $\pm 0.6 \mathrm{gm})$ and 9 CORT-implanted $(24.4 \pm 0.9 \mathrm{gm})$ rats.

Adrenalectomy and CORT replacement. The $\mathrm{HC}$ is a target for the negative feedback effects of glucocorticoids and its removal is associated with elevations in pituitary-adrenal hormones and their secretagogues (Knigge, 1961; Murphy et al., 1979; Feldman and Confronti, 1980; Wilson et al., 1980; Herman et al., 1989; Jacobson and Sapolsky, 1991). In preweanling rats, elevations in endogenous pituitary-adrenal hormones influence behavioral responding (Takahashi et al., 1991). Thercforc, ADX and exogenous CORT administration procedures were conducted to eliminate the possibility that behavioral differences between sham-operated and lesioned groups, i.e., electrolytic, colchicine, and KA-lesioned rats, were due to effects produced by $\mathrm{HC}$ lesion-induced alterations in hypothalamic-pituitary-adrenal hormone secretion.

Immediately after stereotaxic surgery, a unilateral dorsal incision was made to extract one adrenal gland. The pup was then returned to the nest box containing the unoperated male and female littermates. During this postsurgical period, which generally lasted between 30 to $60 \mathrm{~min}$, the dam was kept in another cage. Once operated pups began to move around the cage, they were reintroduced to their mother. After a $24 \mathrm{hr}$ period, the operated pups were anesthetized with methoxyflurane and the remaining adrenal gland was extracted. Pilot work on rat pups indicated that removal of adrenal glands over a $2 \mathrm{~d}$ period improves survival after stereotaxic surgery. Prior to returning the pup to the nest box, an s.c. injection of $3.0 \mathrm{mg} / \mathrm{kg}$ of CORT was administered. CORT injections were repeated at $24 \mathrm{hr}$ intervals on days 11,12 , and 13 . This dose of CORT is effective in facilitating the development of behavioral inhibition in ADX pups (Takahashi and Rubin, 1993; Takahashi, 1994b).

Apparatus. Tests were conducted in a Plexiglas enclosure $(26.5 \times$ $26.5 \times 20 \mathrm{~cm}$ ) housed in a temperature-controlled incubator with a glass front. The Plexiglas enclosure was subdivided by a wire-mesh partition positioned with the two ends attached to the midportion of two adjacent walls, thereby forming a small triangular compartment. The top was open except for the area above the small triangular compartment, which housed the rat pup. The enclosure was placed on a cardboard floor that was changed after every test. The ultrasonic detector was positioned directly above. Ambient temperature in the incubator varied from 33 to $35^{\circ} \mathrm{C}$. These temperatures are within the thermoneutral range for $14-\mathrm{d}$ old rats (Conklin and Heggeness, 1971).

Behavioral tests. Rat pups were tested on day 14. At this time, an adult male rat was anesthetized with sodium pentobarbital $(50 \mathrm{mg} / \mathrm{kg}$, i.p.) and placed into the large compartment of the test apparatus. The rat pup was then placed in the adjacent triangular compartment.

Behavioral measurements. All behavioral tests were $10 \mathrm{~min}$ in duration and conducted in the first half of the light cycle. During testing, the duration (in seconds) of freezing was recorded using timers. Freezing was scored whenever the pup assumed an immobile posture with the head in a stationary and elevated position. Ultrasonic vocalizations were recorded with a counter. Ultrasounds were detected with headphoncs attached to the socket of a Mini-2 bat detector (Bat Conservation International, Austin, TX) tuned to $40 \mathrm{kHz}$. The bat detector transforms the ultrasound into the audible range of humans. It should be noted that in earlier pilot studies, 14-d-old rat pups consistently emitted ultrasounds that were within the $40 \mathrm{kHz}$ range. Higher or lower frequency ultrasounds beyond the detectable limits of the $40 \mathrm{kHz}$ setting were never heard.

Removal of adrenal hormones reduces the ability of organisms to thermoregulate (Deavers and Musacchia, 1979), which may affect behavioral expression (Allin and Banks, 1971; Blumberg and Alberts, 1990). Therefore, immediately after testing, the pup's rectal temperature was measured using a microprobe (IT-21, Physitemp, Clifton, NJ) attached to a BAT-12 digital thermometer, with a resolution of $0.1^{\circ} \mathrm{C}$. The probe was inserted into the rectum to a depth of $10 \mathrm{~mm}$ and held in position until the temperature stabilized. Rectal temperature measurements were obtained within a $10 \mathrm{sec}$ period.
Statistics. Statistical significance was determined using independent $t$ tests. Results are expressed as mean \pm SEM.

\section{Results}

Effects of hippocampal lesions on behavioral inhibition

Histological results. The extent of electrolytic lesions produced in the $\mathrm{HC}$ formation is shown in Figure 1. Damage in the region of the dorsal $\mathrm{HC}$ was symmetrical and invariably included the dentate gyrus (see coronal sections A2.0 and A2.9 in Fig. 1). At these levels of the $\mathrm{HC}$ formation, the $\mathrm{CA} 3$ region underwent the least destruction. However, in posterior regions of the $\mathrm{HC}$, the CA3 regions incurred extensive damage (coronal sections $\mathrm{A} 0.4$ and A1.2 in Fig. 1), whereas destruction to dorsal and ventral dentate gyrus was considerably less severe. Finally, the posterior boundary of the lesions extended into the dentate gyrus (coronal section A0.0 in Fig. 1). In addition to damage in the dorsal $\mathrm{HC}$ region, there was variable damage to the corpus callosum and overlying neocortex. In posterior HC regions, minor damage was occasionally found in the lateral and medial geniculate nucleus.

Behavioral results. Administration of exogenous CORT was ineffective in facilitating freezing in rat pups bearing $\mathrm{HC}$ lesions. As shown in Table 1, HC-lesioned pups spent significantly less time engaged in freezing than sham-operated animals, $t(16)=$ $6.90, p<0.01$. No group differences were found in the number of ultrasonic vocalizations, $t(16)=1.09, p>0.05$, which were low. Body temperatures did not differ between sham-operated $(37.0 \pm 0.1)$ and HC-lesioned pups $(37.7 \pm 0.1)$.

\section{Effects of hippocampal granule cell loss on behavioral inhibition}

Histological results. Marked destruction of dentate granule cells was observed $5 \mathrm{~d}$ after bilateral intrahippocampal infusion of colchicine (Fig. 2). In contrast, CA1 to CA3 regions incurred only minor damage. The extent of the damage decreased with distance from the site of injection. Examination of serial sections using low power magnification revealed that dentate granule cell loss occurred within an anterior-posterior distance of 360 to 540 $\mu \mathrm{m}$ from the site of greatest damage. In dorsal $\mathrm{HC}$ regions, the corpus callosum and neocortex overlying the site of injection was also damaged (see Fig. $2 B$ ). Colchicine infusions did not appear to produce major loss of dentate granule cells in the most posterior-ventral $\mathrm{HC}$ regions proximal to the entorhinal cortex.

Behavioral results. Analysis of behavioral data indicated that infusion of colchicine into the HC produced a significant reduction in freezing duration in ADX pups administered exogenous CORT, $t(17)=8.45, p<0.001$ (see Table 2). Ultrasonic vocalizations produced by both groups were low in occurrence and did not differ reliably, $t(17)=0.10, p>0.05$. Body temperatures were also similar between sham-operated and colchicinetreated groups $(37.3 \pm 0.1$ vs $37.3 \pm 0.1$, respectively).

\section{Effects of hippocampal CA3 cell loss on behavioral inhibition}

Histological results. Five days after bilateral intrahippocampal injections of $\mathrm{KA}$, there was a pronounced loss of cells in the hilar region of the dentate gyrus (see Fig. $3 B, C$ ). At the site of injection, the majority of CA3 cells were destroyed. The destruction of hilar cells appeared to produce a reduction in the distance between the dentate granule cell layers that was most notable in the dorsal $\mathrm{HC}$. Although CA3 cells immediately adjacent to those located in the hilar region were also destroyed, the majority of CA3 as well as CA1 and CA2 neurons appeared intact. 


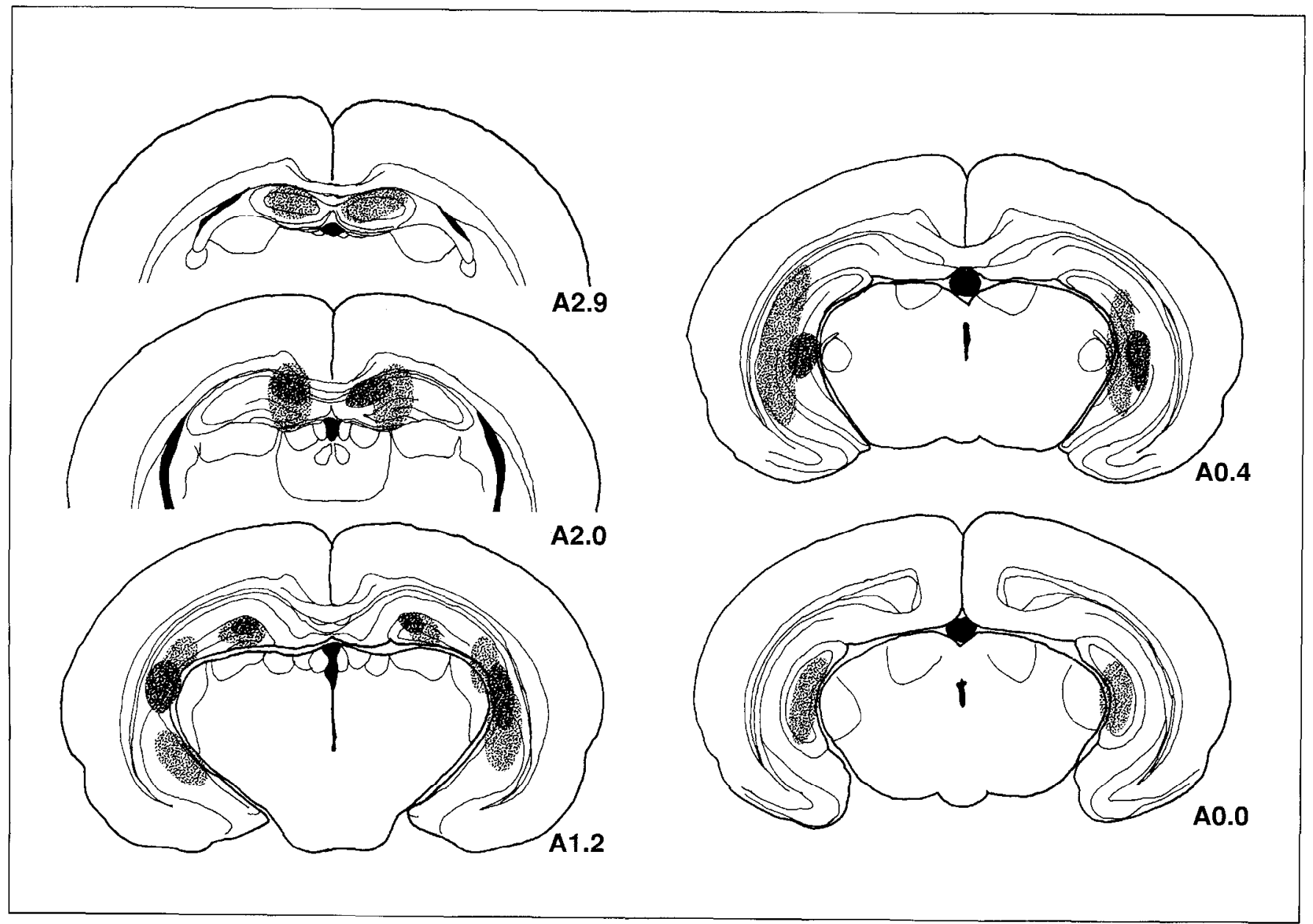

Figure 1. Reconstruction of the extent of hippocampal lesions of rat pups. (The dark areas represent the smallest lesions, whereas the light stippled areas indicate the largest lesions. The number designates the anterior position of the coronal section in mm relative to interaural zero. Plates were adapted from the 10-d-old rat brain atlas of Sherwood and Timiras (1970), with permission.)

Destruction of CA3 cells was present in an anterior-posterior distance of 360 to $450 \mu \mathrm{m}$ from the hilar site of greatest damage.

Behavioral results. Intrahippocampal injections of KA produced no significant reduction in freezing, $t(15)=0.01$ (see Table 3) in ADX rat pups treated with exogenous CORT. In addition, groups did not differ significantly in either ultrasound production, $t(15)=0.25$ (Table 3 ), or body temperature, $t(15)$ $=0.03$ (data not shown).

\section{Effects of CORT action in the dorsal HC on behavioral} inhibition

Histological results. Bilateral implantation sites of 30 gauge cannulae containing either cholesterol or CORT are shown in Figure 4. All cannula tips were located in the dorsal $\mathrm{HC}$, with a majority

Table 1. Mean \pm SEM of behavioral responses in 14-d-old rats after sham operations or $\mathrm{HC}$ lesions

\begin{tabular}{lcc} 
& $\begin{array}{l}\text { Sham-operated } \\
(n=9)\end{array}$ & $\begin{array}{c}\text { HC lesions } \\
(n=9)\end{array}$ \\
\hline Freezing (sec) & $268 \pm 35$ & $20 \pm 8^{*}$ \\
Ultrasonic vocalizations (no.) & $7 \pm 3$ & $3 \pm 1$
\end{tabular}

* Significantly different from sham-operated group, $p<0.01$. in the region that contained the coronal section identified as A2.0. At this coronal level, a number of implantation sites were located in the molecular layer bordering the superior blade of the dentate granule cells. A few implants were also found in the hilus. Only three animals (one cholesterol- and two CORT-implanted pups) had implants located either anterior or posterior to coronal section A2.0. After a $5 \mathrm{~d}$ implantation period, the amount of CORT released from each cannula tip was $8.2 \pm 1.6$ $\mu \mathrm{g}$.

Behavioral results. CORT-implants were highly effective in facilitating freezing in ADX pups in comparison to cholesterol implants, $t(17)=3.48, p<.0 .01$ (Table 4). The emission of ultrasounds, however, did not differ significantly between cholesterol- and CORT-implanted pups $t(17)=0.53$. Body temperature also did not differ reliably between groups, $t(17)=1.02$ (data not shown).

\section{Discussion}

Role of hippocampal dentate granule cells in behavioral inhibition

Results suggest clearly that by the end of the second postnatal week the HC plays a prominent role in the expression of behavioral inhibition. More specifically, data suggest that $\mathrm{HC}$ dentate granule neurons play an essential role in mediating the ef- 

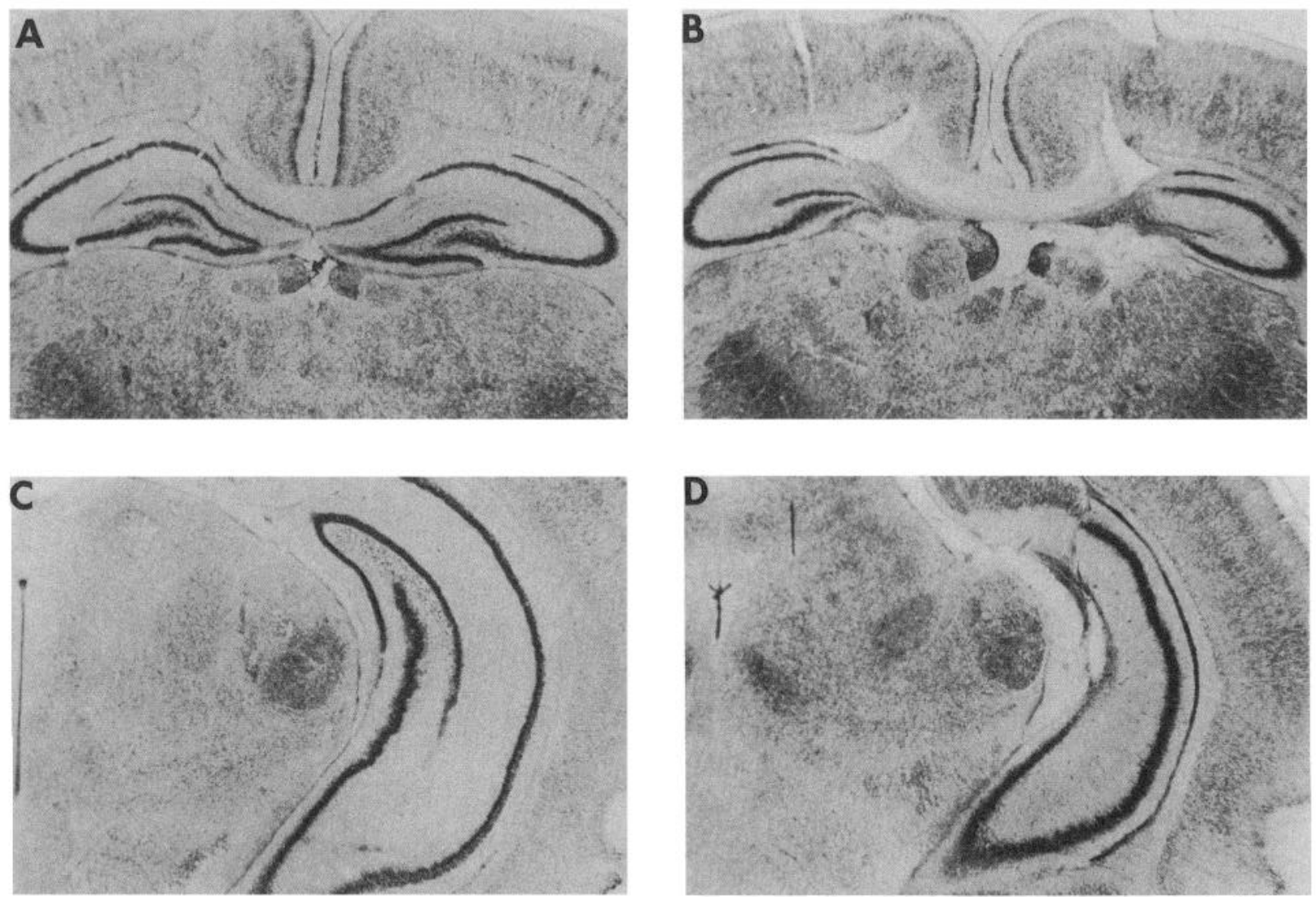

Figure 2. Photomicrographs of thionine-stained $60 \mu \mathrm{m}$ sections of dorsal and posterior hippocampal regions in control (A and C) and colchicinetreated ( $25 \mathrm{ng} / 0.25 \mu \mathrm{l} / \mathrm{site}, B$ and $D$ ) rat pups. A typical dorsal hippocampal lesion induced by colchicine produced extensive damage, especially to the inferior blade of the dentate granule cell layer, as depicted in the right hippocampus of section $B$. In this rat pup, left dorsal hippocampal dentate granule cells were severely damaged approximately $120 \mu \mathrm{m}$ anterior to plate $B$. Note in $D$ the extensive loss of dentate granule cells in the region of the ventral hippocampus. At both dorsal and ventral hippocampal regions, hilar pyramidal cells also appeared to be damaged.

fects of CORT on freezing. This conclusion appears to be supported by the finding that KA-induced destruction of pyramidal CA3 cells in the hilar region was ineffective in attenuating freezing. Hence, the significant reduction in freezing produced by electrolytic lesions that nonselectively eliminated both dentate granule and pyramidal cells in the HC may be attributed to the specific destruction of dentate granule cells. By implicating the $\mathrm{HC}$, these results now provide the basis to examine in detail the $\mathrm{HC}$ mechanisms responsible for mediating the emergence and display of behavioral inhibition.

The entorhinal cortex constitutes the major source of afferents to the dentate gyrus via the perforant pathway (Lorente de No, 1934; Blackstead, 1958; Raisman et al., 1965; Amaral and Witter, 1989). Within the dentate gyrus, granule cells and their mossy fiber axons are the main sources of output to cells in the hilus, CA3 and CA2 fields of the HC (Swanson et al. 1978;

Table 2. Mean \pm SEM of behavioral responses in 14-d-old rats after sham operations or $\mathrm{HC}$ colchicine lesions

\begin{tabular}{lcc} 
& $\begin{array}{l}\text { Sham- } \\
\text { operated } \\
(n=9)\end{array}$ & $\begin{array}{l}\text { Colchicine } \\
\text { lesions } \\
(n=10)\end{array}$ \\
\hline Freezing (sec) & $407 \pm 27$ & $66 \pm 30^{*}$ \\
Ultrasonic vocalizations (no.) & $3 \pm 2$ & $3 \pm 2$
\end{tabular}

\footnotetext{
* Significantly different from sham-operated group, $p<0.001$
}

Gaarskjaer, 1986). Present results suggest that colchicine-induced destruction of dentate granule cells critically undermines the functional integrity of these intrinsic connections, thereby severely compromising the rat pup's ability to exhibit freezing. Furthermore, mossy fiber projections to pyramidal cells distal to those located in the hilus and CA3c regions appear to be sufficient to maintain freezing. This view is supported by the observation that pups appeared fully capable of freezing after KAinduced destruction of CA3 cells in the hilus. From a developmental and behavioral perspective, the importance of dentate granule cells and their mossy fiber projections is clear because it is not until the end of the second postnatal week that mossy terminals in field CA3 attain an adult-like appearance (Amaral and Dent, 1981) and the ability to freeze emerges in rats (Collier and Bolles, 1980; Takahashi, 1992b). In addition, the distribution of entorhinal afferents in the molecular layer of the dentate gyrus finally develops an appearance comparable to that of mature animals by postnatal day 12 (Cowan et al., 1980).

Although the posterior-ventral dentate granule cells adjacent to the entorhinal cortex appeared, for the most part, to be spared, it is not certain whether elimination of the dorsal $\mathrm{HC}$ dentate granule cells is sufficient to produce an attenuation in freezing. An early report demonstrated that after exposure to electrolytic lesions that produced extensive damage throughout the $\mathrm{HC}$ formation, adult rats exhibited a marked reduction in freezing in the presence of a cat (Blanchard and Blanchard, 1972). How- 

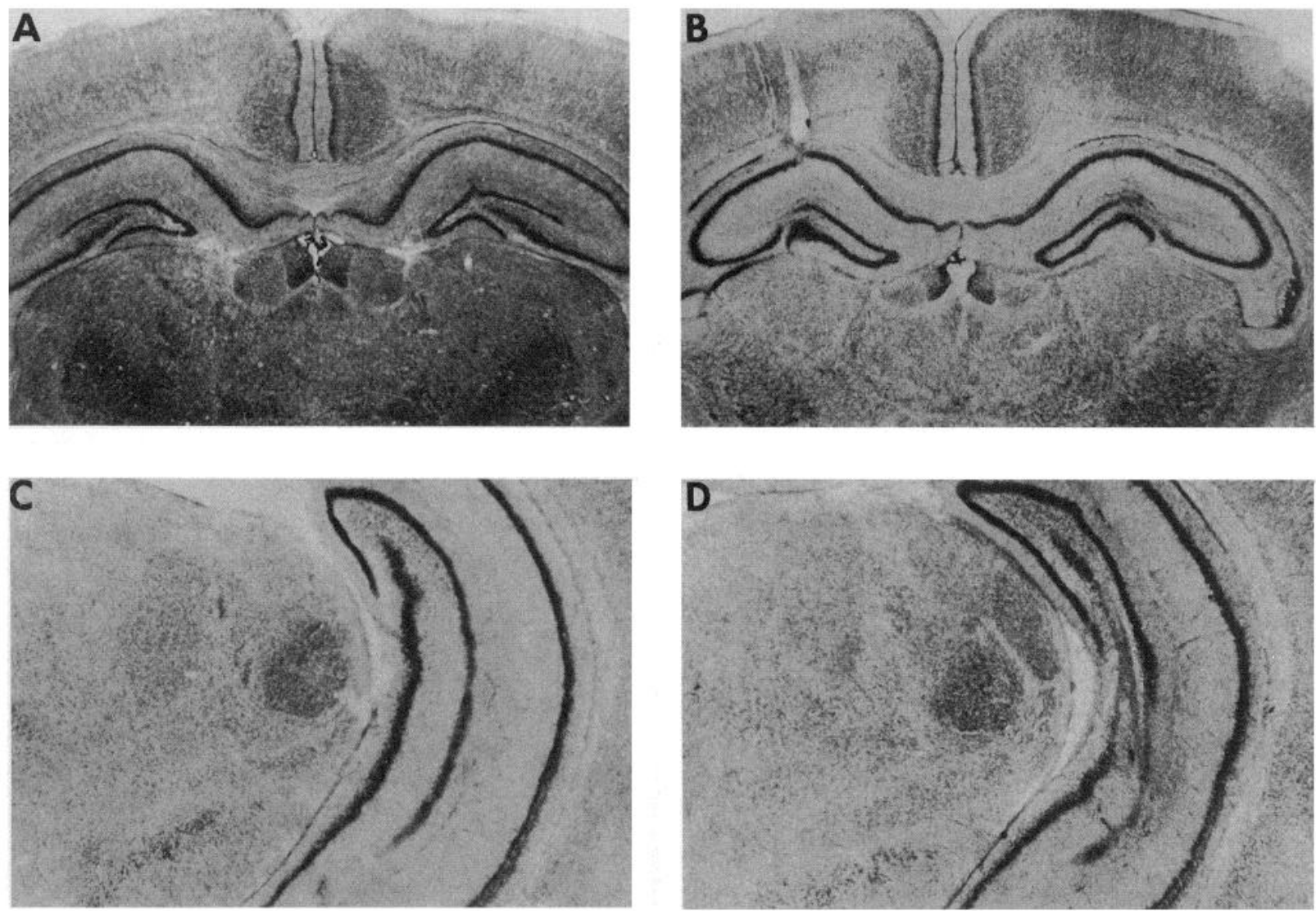

Figure 3. Photomicrographs of thionine-stained $60 \mu \mathrm{m}$ sections of dorsal and posterior hippocampal regions in control $(A$ and $C)$ and KA-lesioned $(100 \mathrm{ng} / 0.5 \mu \mathrm{l} / \mathrm{site}, B$ and $D)$ rat pups. In both dorsal and posterior hippocampal regions, KA produced an extensive loss of cells in the hilar region. Variable damage was also evident in the immediately adjacent CA3 cells. Dentate granule cells appeared to incur only minor damage.

ever, in other studies using adult rats, electrolytic lesions confined to the dorsal $\mathrm{HC}$ that destroyed both the dentate gyrus and fields CA1 and CA3 were not sufficient to reduce freezing induced by stimuli associated with foot shock (Kim and Fanselow, 1992; Phillips and LeDoux, 1992). Between-study differences in the stimulus used to elicit freezing may account for either the presence or reduction in freezing occurring after $\mathrm{HC}$ lesions. It is also possible that potential physiological differences between dorsal and ventral HC regions (e.g., Garcia Ruiz et al., 1993) differentially influence behavioral expression, depending on the nature of the test situation. For instance, some investigators reported that aspiration lesions of the ventral $\mathrm{HC}$ were effective in producing rats with deficits in a conditioned suppression water-lick test (Clark et al., 1992). In addition, cholinergic receptor antagonists infused into the ventral $\mathrm{HC}$ region, in the area of the entorhinal cortex, were more effective in producing behavioral alterations than infusions made into the dorsal HC (Blozovski, 1979; Blozovski and Hennocq, 1982). Other investigators re-

Table 3. Mean \pm SEM of behavioral responses in 14-d-old rats after sham operations or HC kainic acid lesions

\begin{tabular}{lcc} 
& $\begin{array}{l}\text { Sham- } \\
\text { operated } \\
(n=8)\end{array}$ & $\begin{array}{l}\text { KA } \\
\text { lesions } \\
(n=9)\end{array}$ \\
\hline Freezing (sec) & $370 \pm 53$ & $369 \pm 51$ \\
Ultrasonic vocalizations (no.) & $4 \pm 2$ & $5 \pm 4$
\end{tabular}

ported that spatial learning deficits reflect the magnitude of dorsal HC damage, whereas ventral HC lesions are generally without effect (Moser et al., 1993).

The basis underlying the attenuation of freezing after loss of cells in the dentate gyrus remains to be precisely specified. Adult rats with large lesions of the $\mathrm{HC}$ showed an increase in locomotor activity in the presence of a cat but not prior to the cat's introduction (Blanchard and Blanchard, 1972). In other studies, dentate granule cell loss was associated with increased locomotor activity that may account for deficits reported to occur in passive avoidance tests (Haggbloom et al., 1974; Walsh et al, 1986). Although ambulatory movements were not measured in the present experiments, it is possible that colchicine-induced attenuation in rat pup freezing is due to a potentiated increase in behavioral movements. The inability to suppress certain behavioral responses coupled with an increase in movement-related behavior were among the cardinal manifestations reported in early studies of HC lesions (Issacson and Wickelgren, 1962; Douglas, 1967; Kimble, 1968). Subsequent research suggests that increased behavioral movements occurring after HC lesions may be due, in part, to alterations in dopamine activity in the nucleus accumbens (Reinstein et al., 1982), a target of HC projections (Raisman et al., 1966; Swanson and Cowan, 1977; Kelley and Domesick, 1982).

An increase in behavioral movements, however, is not the only interpretation that may account for a deficit in freezing. Alterations in neural function arising from the destruction of dentate granule cells may be occurring in a manner that biolog- 


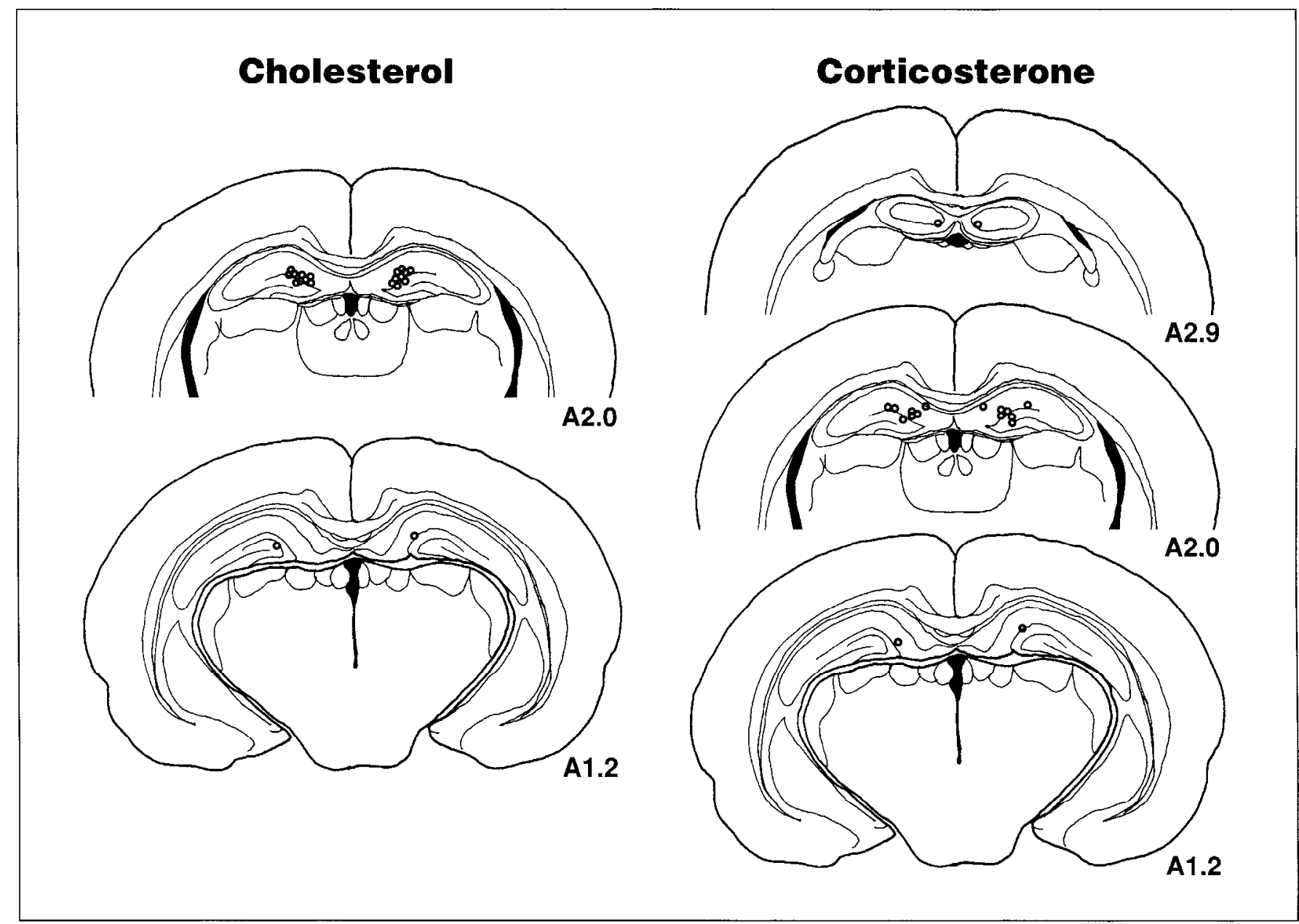

Figure 4. Location of bilateral 30 gauge cannula tips containing either cholesterol or corticosterone in the dentate gyrus of 14-d-old rat pups. (The number designates the anterior position of the coronal section in $\mathrm{mm}$ relative to interaural zero. Plates were adapted from the 10-d-old rat brain atlas of Sherwood and 'l'imiras (1970), with permission.)

ically relevant stimuli are no longer integrated in an adaptive manner (Deadwyler et al., 1981). The HC system was initially proposed to play an important role in the processing of olfactory stimuli (Brodal, 1947), and recent electrophysiological studies demonstrate that cells of the dentate gyrus respond to olfactory stimuli (Vanderwolf, 1992). Of particular relevance are studies demonstrating that odors of predators potentiate fast wave bursts in the dentate gyrus of rats (Heale et al., 1994). In addition, odor-guided learning and memory appear to be dependent upon an intact HC system (Staubli et al., 1984; Eichenbaum et al., 1991). Accordingly, destruction of dentate granule cells may impair not only the rat pup's ability to respond appropriately to odors associated with threat but also the integration of unfamiliar

Table 4. Mean \pm SEM of behavioral responses in 14-d-old rats after implantation of 30 gauge cannulae containing cholesterol or CORT in the dorsal $\mathrm{HC}$

\begin{tabular}{lll} 
& $\begin{array}{l}\text { Cholesterol } \\
\text { implants } \\
(n=10)\end{array}$ & $\begin{array}{l}\text { CORT } \\
\text { implants } \\
(n=9)\end{array}$ \\
\hline Freezing (sec) & $142 \pm 36$ & $301 \pm 9 *$ \\
Ultrasonic vocalizations (no.) & $34+20$ & $21 \pm 10$
\end{tabular}

\footnotetext{
* Significantly different from cholesterol implants, $p<0.01$.
}

with familiar odors that may further contribute to the observed disruption in freezing.

It should be noted that although the pup could view the adult male through the wire-mesh partition, visual cues probably do not contribute significantly to the clicitation of freczing. In this strain of rats, approximately $40 \%$ of 14 -d-old pups do not have fully opened eyes (Takahashi, 1994b). Importantly, they do not differ in freezing from pups with opened eyes. Additionally, previous studies (Takahashi, 1994b) demonstrated that rat pups readily exhibit behavioral inhibition in the presence of an unfamiliar adult male rat, whereas similar-sized but familiar adult male rats are ineffective in potentiating behavioral inhibition. Thus, HC dentate granule cells may be an important component of an odor-based memory system that guides or directs bchavioral responses accordingly to the nature of the odor and its degree of familiarity.

In addition to a putative role underlying the integration of olfactory information, data suggest strongly an involvement of dentate granule cells in spatial and nonspatial memory. Colchicine-induced loss of dentate cells in adulthood was shown to produce deficits in both the Morris water maze (Sutherland et al., 1983) and radial-arm maze tasks (Walsh et al., 1986; Emerich and Walsh, 1990). Other experimental procedures that induce a loss of granule cells such as long-term ADX (Sloviter et al., 
1989; Sapolsky et al., 1991) were also effective in impairing spatial learning in the Morris water maze (Conrad and Roy, 1993). In studies using infant rats, $x$-irradiation-induced granule cell hypoplasia produced deficits in patterned alternation (DiazGranados et al., 1992), a form of nonspatial memory-based learning. Damage to the HC formation that includes the dentate gyrus also disrupts configural discrimination (Rudy and Sutherland, 1989; Sutherland et al., 1989), another form of nonspatial learning. Together, data suggest that the reduction in freezing is not a specific outcome of dentate granule cell loss. The potential relevance of these studies for understanding behavioral inhibition, however, is that it underscores the involvement of the $\mathrm{HC}$ in cognitive functions. The risk of predation exerts a profound influence on animal decision making (Lima and Dill, 1990), which, in turn, is responsible for the occurrence of overt patterns of behavior, e.g., freezing. Disruption of hippocampal function may influence cognitive integration in potentially harmful situations in number of different ways. As indicated earlier, important olfactory stimuli may not be readily perceived. Even if the stimulus is perceived, appropriate attention to the stimuli may not be forthcoming, resulting in the production of atypical responses. The $\mathrm{HC}$ formation may be a neural structure suitable for future developmental neurobiological studies of risk assessment.

\section{Role of hippocampal CA3 cells in behavioral inhibition}

Studies indicate that systemic administration of KA is less effective in producing widespread damage to $\mathrm{CA} 3$ cells in young rat pups (Albala et al., 1984; Nitecka et al., 1984; Sperber et al., 1991). Although the current study employed intrahippocampal infusion techniques, the amount of damage to the CA3 field of the $\mathrm{HC}$ still appears less severe than that observed in intrahippocampal KA-treated adult rats in which cells throughout the CA3 field were damaged (Fornnum and Walaas, 1978; Nadler and Cuthbertson, 1980). The potential implication is that widespread loss of CA3 cells in pups may increase the likelihood of producing alterations in behavioral inhibition that are not altogether different from those occurring after intrahippocampal colchicine infusions. In support of this view, studies demonstrate that after KA treatment, adult rats exhibited deficits in the Morris water maze (Sutherland et al., 1983) as well as in the passive avoidance test (Munoz and Grossman, 1981). Similar alterations were also evident after colchicine-induced damage to dentate granule cells (Sutherland et al., 1983; Walsh et al, 1986). These data implicate a role of $\mathrm{CA} 3$ cells in behavioral functions and suggest they may have an important, but as yet undefined role, in modulating mossy fiber inputs activated by appropriate stimuli.

Nonetheless, the loss of CA3 cells in the region of the hilus, where damage was most extensive, produced no significant change in behavioral inhibition. This result suggests that mossy fiber inputs to these cells do not contribute importantly to the expression of behavioral inhibition. In addition, the resultant loss of CA3 fibers originating in the region of the hilus and projecting to field CA1 (Swanson et al., 1978; Ishizuka et al., 1990) also appears to have minimal effects on the occurrence of behavioral inhibition. At the very least, these results serve to clarify the nature of the colchicine-induced damage and its behavioral consequences. That is, any incidental damage to CA 3 hilus cells arising from infusion of colchicine was probably not a significant factor in the production of behavioral inhibitory deficits.

\section{CORT action in the $H C$ and behavioral inhibition}

Bilateral CORT-filled cannulae located in the dorsal dentate gyrus of ADX pups were effective in promoting freezing. This result extends considerably previous work conducted in this laboratory documenting the reinstating effects of CORT on behavioral inhibition after systemic (Takahashi and Rubin, 1993; Takahashi, 1994c) or intraventricular administration of exogenous CORT (Takahashi and Kim, 1994). Furthermore, in the majority of CORT-implanted pups, plasma concentrations of CORT were nondetectable, which suggest that the action of CORT did not extend appreciably beyond the brain. Thus, central actions of CORT appear sufficient to facilitate the occurrence of freezing in the ADX rat pup. Whether other brain sites that bind CORT (Reul and de Kloet, 1985; Rosenfeld et al., 1990) will also produce behavioral effects similar to those occurring after implantation in the $\mathrm{HC}$ remains to be answered.

It should be indicated that the HC manipulations used in this study, i.e., electrolytic lesions, selective neurotoxins, CORT implants, had dramatic effects on freezing, whereas no significant changes were detected in ultrasonic vocalizations. These results suggest that the action of CORT in the HC may not have a major role in regulating ultrasound production. Furthermore, examination of ultrasound data presented in Tables 1 to 4 suggest, instead, that the action of exogenous CORT in extrahippocampal regions may be involved in the suppression of ultrasounds. When the action of CORT is limited to the HC region (Table 4), ultrasound production does not appear to be as effectively suppressed (Tables 1 to 3 ). The putative extrahippocampal suppressive effects of CORT on ultrasound production may account for the higher production of ultrasounds made by ADX pups in comparison to intact animals (Takahashi and Rubin, 1993).

Studies indicate that $\mathrm{HC}$ dentate granule cells bind and are developmentally regulated by adrenal steroids (Gould et al., 1991a,b). Because in these previous studies the source of exogenous CORT was from the periphery, it is unclear whether the effects of CORT on dentate granule cell development were due to hormone action occurring specifically in the HC. In the current study, exogenous CORT was delivered via cannulae located in the dorsal dentate gyrus. Although the amount of hormone diffusion from the 30 gauge cannula tip is not known, the amount of CORT released (i.e., approximately $8 \mu \mathrm{g}$ ) during the $5 \mathrm{~d}$ implantation period probably did not diffuse considerably beyond the HC. Other investigators who implanted larger 24 gauge cannula into the medial prefrontal cortex reported that after a $4 \mathrm{~d}$ implantation period approximately $30 \mu \mathrm{g}$ of CORT was released and the amount of diffusion was confined to a 1 $\mathrm{mm}$ region surrounding the cannula tip (Diorio et al., 1993). Hence, the action of CORT may be confined largely to the region of the dorsal $\mathrm{HC}$ dentate granule cells. This local hormone action appears sufficient to maintain the developmental regulation of dentate granule cells important in facilitating the onset of behavioral inhibition.

Although results of this study emphasize the developmental actions of CORT on $\mathrm{HC}$ dentate gyrus development and behavior, previous studies showed that glucocorticoids are capable of producing toxic effects on the adult and developing HC (Sapolsky et al., 1985, Sapolsky et al., 1990, Uno et al., 1990). These studies showed that in rodents and primates, CA3 cells are most vulnerable to high doses of glucocorticoids, whereas other pyramidal cells and dentate granule neurons are relatively resistant. It is unlikely, however, that the occurrence of freezing observed 
after implantation of CORT into the $\mathrm{HC}$ was a result of glucocorticoid-induced damage to CA3 cells. In the present study, $\mathrm{KA}$-induced damage to $\mathrm{CA} 3$ cells in proximity to the hilus produced no significant change in the propensity of rats to exhibit behavioral inhibition. Another possibility is that behavioral inhibition was facilitated by CORT-induced destruction of $\mathrm{HC}$ cells other than CA3 cells. This scenario, however, is highly unlikely because CA 3 cells are most susceptible to the damaging effects of glucocorticoids.

$\Lambda$ nother possible interpretation that may explain the induction of freezing after dorsal HC implantation of CORT is that negative feedback effects of the CORT implant contributed to a normalization of pituitary ACTH and its secretagogues that were elevated after ADX. In adult rats, elevated secretion of pituitary hormones was implicated in the production of deficits in avoidance behavior (Weiss et al., 1970). In addition, dorsal hippocampectomy (Feldman and Conforti, 1980) or dorsal dentale gyrus lesions (Johnson and Moberg, 1980) alter the negative feedback effects of glucocorticoids. Implantation of CORT into the dorsal $\mathrm{HC}$ was also more effective than cholesterol implants in attenuating the ADX-induced elevation of ACTH (Kovacs and Makara, 1988), especially when placed in CA2 and CA3 fields (Kawakami et al., 1968). Nevertheless, previous studies revealed that hypophysectomized-ADX pups continued to exhibit deficits in behavioral inhibition, which suggest that reduced secretion of pituitary hormones does not ameliorate the ADX-induced deficits in behavioral inhibition (Takahashi and Kim, 1995). Normalization of feedback effects produced by bilateral $\mathrm{HC}$ implants of CORT is unlikely to be a factor that contributes importantly to the reinstatement of freezing after ADX.

The HC not only binds CORT but is also a site of action of varied neurotransmitters including norepinephrine (Moore and Bloom, 1979), serotonin (Moore and Halaris, 1975), acetylcholine (Lewis and Shute, 1967; Matthews et al., 1987), and glutamate (Cotman et al., 1981; Storm-Mathisen, 1981; StormMathisen and Iversen, 1979). Moreover, studies demonstrate that glucocorticoids influence second-messenger systems (Mobley and Sulser, 1980) and neurotransmitter receptor binding (Biegon et al., 1985). During development, glucocorticoids facilitate the increase in tryptophan hydroxylase (Sze et al., 1976) thereby contributing to the development of the serotonin system. It is possible that $\Lambda \mathrm{DX}$ severely disrupted the varied effects of glucocorticoids on neurotransmitter systems (McEwen et al., 1986; De Kloet, 1991), which resulted in freezing deficits. It should be emphasized that ADX is most effective in producing deficits in freezing when conducted prior to postnatal day 14 (Takahashi, 1994c). Furthermore, exogenous CORT is highly effective in reinstating freezing in the ADX pup only when administered on days immediately following ADX. After an ADX-induced period of absence of CORT, subsequent administration of exogenous CORT failed to facilitate the occurrence of freezing. Therefore, any behavioral inhibitory alterations produced by effects of ADX and CORT on neurotransmitter systems must be demonstrated to occur developmentally or prior to the appearance of behavioral inhibition. Neurotransmitter alterations induced by an acute presence or absence of CORT without developmental significance may not be of relevance to an understanding of mechanisms underlying the current behavioral responses.

Long-term ADX produces marked degeneration of $\mathrm{HC}$ dentate granule cells (Sloviter et al., 1989; Sapolsky et al., 1991), and loss of these cells may underlie the deficits in freezing. It is particularly notable that the ADX-induced degeneration of dentale granule cells is more severe in younger than in older rats (Jaarsma et al., 1992). Although during the inspection of cholesterol implantation sites there was no dramatic absence of dentate granule cells similar to that occurring after colchicine infusion, it is highly possible that ADX-induced alterations were already present. Studies have indicated that in adult rats the appearance of pyknotic granule cells was evident by 3 to $7 \mathrm{~d}$ after ADX (Gould et al., 1990). In contrast, cells in CA fields were not altered. Furthermore, death of dentate granule cells in ADX rats was prevented by administration of exogenous CORT. These data reveal the specificity of the ADX-induced loss of cells in the $\mathrm{HC}$ formation and the importance of corticosteroids in maintaining survival of dentate granule neurons. An implication of this research is that alterations in endogenous corticosteroid secretion occurring during the period of rapid $\mathrm{HC}$ dentate granule cell development may alter $\mathrm{HC}$ functional development in such a way that individuals are at risk or predisposed to perform poorly in situations requiring a degree of attentiveness to relevant stimuli and rapid cessation of overt movements. That effects of early ADX are long lasting is evident from studies showing that in adulthood, rats that were ADX on day 11 had reduced latencies to leave a start box and exhibited high levels of running wheel activity (Yehuda et al., 1988). These findings further suggest that even in adulthood, rats that were ADX in early life are less behaviorally inhibited.

\section{References}

Albala BJ, Moshe SL, Okada R (1984) Kainic-acid-induced seizure: a developmental study. Dev Brain Res 13:139-148.

Allin JT, Banks EM (1971) Effects of temperature on ultrasound production by infant albino rats. Dev Psychobiol 4:149-156.

Allin JT, Banks EM (1972) Functional aspects of ultrasound production in infant albino rats. Anim Behav 20:175-185.

Altman J, Brunner RL, Bayer SA (1973) The hippocampus and behavioral maturation. Behav Biol 8:557-596.

Altman J, Das GD (1965) Autoradiographic and histological evidence of postnatal hippocampal neurogenesis in rats. J Comp Neurol 124 319-336.

Amaral DG, Dent JA (1981) Development of the mossy fibers of the dentate gyrus: I. A light and electron microscopic study of the mossy fibers and their expansions. J Comp Neurol 195:51-86.

Amaral DG, Witter MP (1989) The three dimensional organization of the hippocampal formation: a review of anatomical data. Neuroscience 31:571-591.

Bayer, SA (1980a) Development of the hippocampal region in the rat I. Neurogenesis examined with ${ }^{3} \mathrm{H}$-thymidine autoradiography. I Comp Neurol 190:87-114.

Bayer, SA (1980b) Development of the hippocampal region in the rat II. Morphogenesis during embryonic and early postnatal life. J Comp Neurol 190:115-134.

Ben-Ari Y, Tremblay E, Berger M, Nitecka L (1984) Kainic acid seizure syndrome and binding sites in developing rats. Dev Brain Res $14: 284-288$.

Biederman J, Rosenbaum JF, Hirshfeld DR, Faraone SV, Bolduc EA Gersten M, Meminger SR, Kagan J, Snidman N, Reznick JS (1990) Psychiatric correlates of behavioral inhibition in young children of parents with and without psychiatric disorders. Arch Gen Psychiatry 47:21-26.

Biegon A, Rainbow TC, McEwen BS (1985) Corticosterone modulation of neurotransmitter receptors in rat hippocampus: a quantitative autoradiographic study. Brain Res 332:309-314.

Blanchard DC, Blanchard RJ (1988) Ethoexperimental approaches to the biology of emotion. Annu Rev Psychol 39:43-68.

Blanchard RJ, Blanchard DC (1972) Effects of hippocampal lesions on the rat's reaction to a cat. J Comp Physiol Psychol 78:77-82.

Blackstad TW (1958) On the termination of some afferents to the hippocampus and facia dentata. An experimental study in the rat. Acta Anat 35:202-214.

Blozovski D (1979) PA-learning in young rats with dorsal hippocam- 
pal- and hippocampo-entorhinal atropine. Pharmacol Biochem Behav 10:369-372.

Blozovski D, Hennocq N (1982) Effects of antimuscarinic cholinergic drugs injected systemically or into the hippocampo-entorhinal area upon passive avoidance learning in young rats. Psychopharmacology (Berlin) 76:351-358.

Blumberg MS, Alberts JR (1990) Ultrasonic vocalizations by rat pups in the cold: an acoustic by-product of laryngeal braking? Behav Neurosci 104:808-817.

Brodal A (1947) 'The hippocampus and the sense of smell: a review. Brain 70:179-222.

Cherubini E, De Feo MR, Mecarelli O, Ricci GF (1983) Behavioral and electrographic patterns induced by systemic administration of kainic acid in developing rats. Dev Brain Res 9:69-77.

Clark AJM, Feldon J, Rawlins JNP (1992) Aspiration lesions of rat ventral hippocampus disinhibit responding in conditioned suppression or extinction, but spare latent inhibition and the partial reinforcement extinction effect. Neuroscience 48:821-829.

Collier AC, Bolles RC (1980) The ontogenesis of defensive reactions to shock in preweanling rats. Dev Psychobiol 13:141-150.

Conklin P, Heggeness FW (1971) Maturation of temperature homeostasis in the rat. Am $\mathbf{J}$ Physiol 220:333-336.

Conrad CD, Roy E J (1993) Selective loss of hippocampal granule cell following adrenalectomy: implications for spatial memory. J Neurosci $13: 2582-2590$

Cotman CW, Foster A, Lanthorn T (1981) An overview of glutamate as a neurotransmitter. Adv Biochem Psychopharmacol 2:1-27.

Cowan WM, Stanfield BB, Kishi K (1980) The development of the dentate gyrus. Curr Top Dev Biol 15:103-157.

Curio E (1976) The ethology of predation. New York: Springer.

Davis $M$ (1982) The role of the amygdala in fear and anxiety. Annu Rev Neurosci 15:353-375.

Deadwyler SA, West MO, Robinson JH (1981) Entorhinal and septal inputs differentially control sensory-evoked responses in the rat dentate gyrus. Science 211:1181-1183.

Deavers DR, Musacchia XJ (1979) The function of glucocorticoids in thermogenesis. Fed Proc 38:2177-2181.

De Ghett VJ (1974) Developmental changes in the rate of ultrasonic vocalization in the Mongolian gerbil. Dev Psychobiol 7:267-272.

De Kloet ER (1991) Brain corticosteroid receptor balance and homeostatic control. Front Neuroendocrinol 12:95-164.

De Kloet ER, De Kock S, Schild V, Veldhuis HD (1988) Antiglucocorticoid RU 38486 attenuates retention of a behavior and disinhibits the hypothalamic-pituitary adrenal axis at different brain sites. Neuroendocrinology 47:109-115.

Diaz-Granados JL, Greene PL, Amsel A (1992) Memory-based learning in preweanling and adult rats after infantile $x$-irradiation-induced hippocampal granule cell hypoplasia. Behav Neurosci 106:940-946.

Diorio D, Viau V, Meaney MJ (1993) The role of the medial prefrontal cortex (cingulate gyrus) in the regulation of hypothalamic-pituitaryadrenal responses to stress. J Neurosci 13:3839-3847.

Douglas RJ (1967) The hippocampus and behavior. Psychol Bull 67: 416-422.

Doupe AJ, Patterson PH (1982) Glucocorticoids and the developing nervous system. In: Adrenal actions on brain (Ganten D, Pfaff D, eds), pp 23-43. New York: Springer.

Eichenbaum H, Cohen NJ, Otto T, Wible C (1991) Memory representation in the hippocampus: functional domain and functional organization. In: Memory: organization and locus of change (Squire LR, Weinberger NM, Lynch G, McGaugh JL, eds), pp 163-204. New York: Oxford UP.

Emerich, DF, Walsh, TJ (1990) Cholinergic cell loss and cognitive impairments following intraventricular or intradentate injection of colchicine. Brain Res 517:157-167.

Feldman S, Confronti N (1980) Participation of the dorsal hippocampus in the glucocorticoid feedback effect on adrenocortical activity. Neuroendocrinology 30:52 61 .

Fonnum F, Walaas I (1978) The effect of intrahippocampal kainic acid injections and surgical lesions on neurotransmitters in hippocampus and septum. J Neurochem 31:1173-1181.

Gaarskjaer FB (1986) The organization and development of the hippocampal mossy fiber system. Brain Res Rev 11:335-357.

Garcia Ruiz AJ, Zambelli M, La Porta C, Ladinsky H, Consolo S (1993) Differences between rat dorsal and ventral hippocampus in muscarinic receptor agonist binding and interaction with phospholipase C. Eur J Pharmacol 244:125-131.

Gerlach JL McEwen BS (1972) Rat brain binds adrenal steroid hormone: radioautography of hippocampus with corticosterone. Science $175: 1133-1136$

Gould E, Woolley CS, McEwen BS (1990) Short-term glucocorticoid manipulations affect neuronal morphology and survival in the adult dentate gyrus. Neuroscience 37:367-375.

Gould E, Woolley CS, McEwen BS (1991a) Adrenal steroids regulate postnatal developnent of the rat dentate gyrus: I. Effects of glucocorticoids on cell death. J Comp Neurol 313:479-485.

Gould E, Woolley CS, Cameron HA, Daniels DC, McEwen BS (1991b) Adrenal steroids regulate postnatal development of the rat dentate gyrus: II. Effects of glucocorticoids and mineralocorticoids on cell death. J Comp Neurol 313:486-493.

Gray JA (1982) The neuropsychology of anxiety. New York: Oxford UP.

Haggbloom SJ, Brunner RL, Bayer SA (1974) Effects of hippocampal granule-cell agenesis on acquisition of escape from fear and one-way active-avoidance responses. J Comp Physiol Psychol 86:447-457.

Hart FM, King JA (1966) Distress vocalizations of young in two subspecies of Peromyscus maniculatus. J Mammal 47:287-293.

Heale VR, Vanderwolf CH, Kavaliers M (1994) Components of weasel and fox odors elicit fast wave bursts in the dentate gyrus of rats. Behav Brain Res 63:159-165.

Herman JP, Schafer MK-H, Young EA, Thompson R, Douglass J, Akil H, Watson SJ (1989) Evidence for hippocampal regulation of neuroendocrine neurons of the hypothalamic-pituitary-adrenocortical axis. J Neurosci 9:3072-3082

Isaacson RL, Wickelgren WO (1962) Hippocampal ablation and passive avoidance. Science 138:1104-1106.

Ishizuka N, Weber J, Amaral DG (1990) Organization of intrahippocampal projections originating from $\mathrm{CA} 3$ pyramidal cells in the rat. J Comp Neurol 295:580-623.

Jaarsma D, Postema F, Korf J (1992) Time course and distribution of neuronal degeneration in the dentate gyrus of rat after adrenalectomy: a silver impregnation study. Hippocampus 2:143-150.

Jacobson L, Sapolsky R (1991) The role of the hippocampus in feedback regulation of the hypothalamic-pituitary-adrenocortical axis. Endocr Rev 12:118-134.

Johnson LL, Moberg GP (1980) Adrenocortical response to novelty stress in rats with dentate gyrus lesions. Neuroendocrinology 30:187192.

Kagan J, Reznick JS, Snidman N (1988) Biological bases of childhood shyness. Science 240:167-171

Kawakami M, Seto K, Yoshida K (1968) Influence of corticosterone implantation in limbic structure upon biosynthesis of adrenocortical steroid. Neuroendocrinology 3:349-354.

Kelley AE, Domesick VP (1982) The distribution of the projection from the hippocampal formation to the nucleus accumbens in the rat: an anterograde and retrograde horseradish peroxidase study. Neuroscience 7:2321-2335.

Kim JJ, Fanselow MS (1992) Modality-specific retrograde amnesia of fear. Science 256:675-677.

Kimble DP (1968) The hippocampus and internal inhibition. Psychol Bull 70:285-295.

Knigge KM (1961) Adrenocorticoid responses to stress in rats with lesions in hippocampus and amygdala. Proc Soc Exp Biol Med 108: $18-21$

Kovacs KJ, Makara GB (1988) Corticosterone and dexamethasone act at different brain sites to inhibit adrenalectomy-induced adrenocorticotropin hypersecretion. Brain Res 474:205-210.

Lawson A, Ahima R, Krozowski Z, Harlan R (1991) Postnatal development of corticosteroid receptor immunoreactivity in the rat hippocampus. Dev Brain Res 62:69-79.

LeDoux JE (1987) Emotion. In: Handbook of physiology, Sec 1, The nervous system, Vol 5, Higher functions of the brain, Pt 1 (Plum F, ed), pp 419-459.

Lewis PR, Shute CCD (1967) The cholinergic limbic system: projections to hippocampal formation, medial cortex, nuclei of the ascending cholinergic reticular system and the subfornical organ and supraoptic crest. Brain 90:521-540.

Lima SL, Dill LM (1990) Behavioral decisions made under the risk of predation: a review and prospectus. Can J Zool 68:619-640.

Lorente de No R (1934) Studies on the structure of the cerebral cortex. 
II. Continuation of the study of the Ammonic system. J Psychol Neurol 46:113-117.

Matthews DA, Salvaterra PM, Crawford GD, Houser CR, Vaughn JE (1987) An immunocytochemical study of choline acetyltransferasecontaining neurons and axon terminals in normal and partially deafferented hippocampal formation. Brain Res 402:30-43.

McEwen BS, De Kloet ER, Rostene W (1986) Adrenal steroid receptors and actions in the nervous system. Physiol Rev 66:1121-1188.

Meyer JS (1985) Biochemical effects of corticosterone on neural tissue Physiol Rev 65:946-1020

Mobley PL, Sulser F (1980) Adrenal corticoids regulate sensitivity of noradrenaline coupled adenylate cyclase in brain. Nature 286:608609.

Moore RY, Bloom FE (1979) Central catecholamine neuron systems: anatomy and physiology of norepinephrine and epinephrine systems. Annu Rev Neurosci 2:113-168.

Moore RY, Halaris AE (1975) Hippocampal innervation by serotonin neurons of the midbrain raphe in the rat. J Comp Neurol 164:171183

Moser E, Moser M-B, Andersen P (1993) Spatial learning impairment parallels the magnitude of dorsal hippocampal lesions, but is hardly present following ventral lesions. J Neurosci 13:3916-3925.

Munoz C, Grossman SP (1981) Spatial discrimination, reversal and active and passive avoidance learning in rats with $\mathrm{K} \Lambda$ induced neu ronal depletions in dorsal hippocampus. Brain Res Bull 6:399-406.

Murphy HM, Wideman CH, Brown TS (1979) Plasma corticosterone levels and ulcer formation in rats with hippocampal lesions. Neuroendocrinology 28:123-130.

Nadler JV, Cuthbertson GJ (1980) Kainic acid neurotoxicity toward hippocampal formation: dependence on specific excitatory pathways. Brain Res 195:47-56.

Nitecka L. Tremblay E, Charton G, Bouillot JP, Berger ML, Ben-Ari Y (1984) Maturation of kainic acid seizure-brain damage syndrome in the rat. II. Histopathological sequelae. Neuroscience 13:1073-1094.

Noirot $E$ (1966) Ultra-sounds in young rodents: I. Changes with age in albino mice. Anim Behav 14:459-462.

Noirot $\mathrm{E}$ (1968) Ultrasounds in young rodents: II. Changes in age in albino rals. Anim Behlav 16:129-134.

Noirot E (1972) Ultrasounds and maternal behavior in small rodents. Dev Psychobiol 5:371-387.

Palmer, W (1909) Instinctive stiliness in birds. Auk 26:23-36.

Phillips RG, LeDoux JE (1992) Differential conditioning of amygdala and hippocampus to cued and contextual fear conditioning. Behav Neurosci 106:274-285.

Raisman G, Cowan WM, Powell TPS (1965) The extrinsic afferent commissural and association fibers of the hippocampus. Brain 88: 963-996.

Raisman G, Cowan WM, Powell TPS (1966) An experimental analysis of the efferent projections of the hippocampus. Brain 89:83-101.

Ratner SC (1967) Comparative aspects of hypnosis. In: Handbook of clinical and experimental hypnosis (Gordon JE, ed), pp 550-587. New York: Macmillan.

Reinstein DK, Hannigan JH, Isaacson RL (1982) Time course of certain behavioral changes after hippocampal damage and their alteration by dopaminergic intervention into nucleus accumbens. Pharmacol Biochem Behav 17:193-202.

Reul JMHM, de Kloet ER (1985) Two receptor systems for corticosterone in rat brain: microdistribution and differential occupation. Endocrinology 117:2505-2511.

Roscnberg KM, Denenberg VH, Zarrow MX, Frank BL (1971) Effects of neonatal castration and testosterone on the rat's pup killing behavior and activity. Physiol Behav 7:363-368.

Rosenfeld P, Sutanto W, Levine S, De Kloet ER (1988a) Ontogeny of Type I and Type II corticosteroid receptors in the rat hippocampus. Dev Brain Res 42:113-118.

Rosenfeld P, Van Eekelen JAM, Levine S, De Kloet ER (1988b) Ontogeny of Type 2 glucocorticoid receptor in discrete rat brain regions: an immunocytochemical study. Dev Brain Res 42:119-127.

Rosenfeld P. Sutanto W, Levine S, De Kloet ER (1990) Ontogeny of mineralocorticoid (type 1) receptors in brain and pituitary: an in vivo autoradiographical study. Dev Brain Res 52:57 60.

Rudy JW, Sutherland RJ (1989) The hippocampal formation is necessary for rats to learn and remember configural discriminations. Behav Brain Res 34:97-107.

Sapolsky RM, Krey LC, McEwen BS (1985) Prolonged glucocorticoid exposure reduces hippocampal neuron number: implications for aging. J Neurosci 5:1222-1227.

Sapolsky RM, Uno H, Rebert CS, Finch CE (1990) Hippocampal damage associated with prolonged glucocorticoid exposure in primates. $\mathrm{J}$ Neurosci 10:2897-2902.

Sapolsky RM, Stein-Behrens BA, Armanini MP (1991) Long-term adrenalectomy causes loss of dentate gyrus and pyramidal neurons in the adult hippocampus. Exp Neurol 114:246-249.

Sarrieau A, Sharma S, Meaney MJ (1988) Postnatal development and environmental regulation of hippocampal glucocorticoid and mineralocorticoid receptors. Dev Brain Res 43:158-162.

Schaller GB (1972) The serengeti lion. Chicago: University of Chicago.

Schlessinger AR, Cowan WW, Gottlieb DI (1975) An autoradiographic study of the time of origin and the pattern of granule cell migration in the dentate gyrus of the rat. J Comp Neurol 159:149-176.

Sherwood NM, Timiras PS (1970) A stereotaxic atlas of the developing rat brain. Berkeley: University of California.

Sloviter RS, Valiquette G, Abrams GM, Ronk EC, Sollas AL, Paul LA, Neubort S (1989) Selective loss of hippocampal granule cells in the mature rat brain after adrenalectomy. Science 243:535-538.

Smotherman WP, Bell RW, Starzec J, Elias, J, Zachman TA (1974) Maternal responses to infant vocalizations and olfactory cues in rats and mice. Behav Biol 12:55 66.

Sperber EF, Haas KZ, Stanton PK, Moshe SL (1991) Resistance of the immature hippocampus to seizure-induced synaptic reorganization. Dev Brain Res 60:88-93.

Staubli U, Ivy G, Lynch G (1984) Hippocampal denervation causes rapid forgetting of olfactory information in rats. Proc Natl Acad Sci USA 81:5885-5887.

Storm-Mathisen J (1981) Glutamate in hippocampal pathways. Adv Biochem Psychopharmacol 27:43-55.

Strorm-Mathisen J, Iversen LL (1979) Uptake of ( $\left.{ }^{3} \mathrm{H}\right)$ glutamic acid in excitatory nerve endings: light and electron microscopic observations in the hippocampal formation of the rat. Neuroscience 4:1237-1253.

Stumpf WE (1971) Autoradiographic techniques and the localization of estrogen, androgen and glucocorticoid receptors in the pituitary and brain. Am Zool 11:725-739.

Sutherland RJ, Whishaw IQ, Kolb B (1983) A behavioural analysis of spatial localization following electrolytic, kainate- or colchicine-induced damage to the hippocampal formation in the rat. Behav Brain Res 7:133-153.

Sutherland RJ, MacDonald RJ, Hill CR, Rudy JW (1989) Damage to the hippocampal formation in rats selectively impairs the ability to learn cue relationships. Behav Neural Biol 52:331-356.

Swanson LW, Cowan WM (1977) An autoradiographic study of the organization of the efferent connections of the hippocampal formation in the rat. J Comp Neurol 172:49-84.

Swanson LW, Wyss JM, Cowan WM (1978) An autoradiographic study of the organization of intrahippocampal association pathways in the rat. J Comp Neurol 181:681-715.

Sze PY, Neckers L, Towle AC (1976) Glucocorticoids as a regulatory factor for brain tryptophan hydroxylase. J Neurochem 26:169-173.

Takahashi LK (1992a) Developmental expression of defensive responses during exposure to conspecific adults in preweanling rats (Rattus norvegicus). J Comp Psychol 106:69-77.

Takahashi I.K (1992h) Ontogeny of hehavioral inhibition in the preweanling rat. Physiol Behav 52:493-

Takahashi LK (1994a) Glucocorticoids, the hippocampus and the devclopment of behavioral inhibition in the preweanling rat. Soc Neurosci Abstr 20:372.

Takahashi LK (1994b) Stimulus control of behavioral inhibition in the preweanling rat. Physiol Behav 55:717-721.

Takahashi LK (1994c) Organizing action of corticosterone on the development of behavioral inhibition in the preweanling rat. Dev Brain Res 81:121-127.

Takahashi LK, Kim H (1994) Intracranial action of corticosterone facilitates the development of behavioral inhibition in the adrenalectomized preweanling rat. Neurosci Lett 176:272-276.

Takahashi LK, Kim H (1995) Relative contributions of pituitary-adrenal hormones to the ontogeny of behavioral inhibition in the rat. Physiol Behav 57:711-716.

Takahashi LK, Lore R (1982) Intermale and maternal aggression in adult rats tested at different ages. Physiol Behav 29:1013-1018.

Takahashi LK, Rubin, WW (1993) Corticosteroid induction of threat- 
induced behavioral inhibition in preweanling rats. Behav Neurosci 107:860-866.

Takahashi LK, Turner JG, Kalin NH (1991) Development of stressinduced responses in preweanling rats. Dev Psychobiol 24:341-360.

Tremblay E, Nitecka L, Berger ML, Ben-Ari Y (1984) Maturation of kainic acid seizure-brain damage syndrome in the rat. I. Clinical, electrographic and metabolic observations. Neuroscience 13:10511072.

Uno H, Ishmiller I, Thieme C, Kemnitz JW, Fngle M.I, Boecker EB, Farrell PM (1990) Brain damage induced by prenatal exposure to dexamethasone in fetal rhesus macaques. I. Hippocampus. Dev Brain Res 53:157-167.

Vanderwolf CH (1992) Hippocampal activity, olfaction, and sniffing: an olfactory input to the dentate gyrus. Brain Res 593:197-208.
Van Eekelen JAM, Bohn MC, De Kloet ER (1991) Postnatal ontngeny of mineralocorticoid and glucocorticoid receptor gene expression in regions of the rat tel- and diencephalon. Dev Brain Res 61:33-43.

Walsh TJ, Schulz, DW, Tilson, HA, Schmechel, DE (1986) Colchicineinduced granule cell loss in rat hippocampus: selective behavioral and histological alterations. Brain Res 398:23-36.

Wciss JM, McEwcn BS, Silva MT, Kalkut M (1970) Pituitary-adrenal alterations and fear responding. Am J Physiol 218:864-868.

Wilson M, Greer SE, Greer MA, Roberts L (1980) Hippocampal inhibition of piluitary-adrenocortical function in female rats. Brain Res 197:433-441.

Yehuda R, McDonald D, Heller H, Meyer J (1988) Maze-learning be havior in early adrenalectomized rats. Physiol Behav 44:373-381.

Zippelius HM, Schleidt WM (1956) Ultraschallaute bei jungen mausen: Naturwissenschaften 43:508 